\title{
Impedancemetric NOx Sensor Using YSZ-Based Solid Electrolyte Attached with Oxide Receptor
}

\author{
Hong-Chan $\mathrm{CHO}^{1}$, Satoko TAKASE${ }^{1}$, Jeong-Hwan SONG ${ }^{2}$, Youichi SHIMIZU * \\ ${ }^{1}$ Department of Applied Chemistry, Kyushu Institute of Technology, \\ 1-1 Sensui-cho, Tobata, City of Kitakyushu, 804-8550, Japan \\ *shims@tobata.isc.kyutech.ac.jp \\ ${ }^{2}$ Department of Information and Electronic Materials Engineering, PaiChai University, \\ 155-40 Baejae-ro, Seo-Gu, Daejeon 302-735, Korea
}

\begin{abstract}
New type simple solid-electrolyte $\mathrm{NOx}\left(\mathrm{NOx} ; \mathrm{NO}, \mathrm{NO}_{2}\right)$ sensor devices were fabricated using an yttriastabilized zirconia (YSZ) as an impedance transducer and metal oxides $\left(\mathrm{Fe}_{2} \mathrm{O}_{3}, \mathrm{Co}_{3} \mathrm{O}_{4}, \mathrm{NiO}, \mathrm{CuO}\right.$ and $\mathrm{ZnO}$ ) as receptors. The sensor signal could be simply detected as the impedance change of the only YSZ plate. The sensing performance of the impedancemetric NOx sensor for the detection of NOx in the range $10 \sim 150 \mathrm{ppm}$ at $300 \sim 500^{\circ} \mathrm{C}$ was investigated using $\mathrm{AC}$ impedance analyzer. The $\mathrm{NiO} / \mathrm{YSZ}$-based compact impedancemetric sensor device showed good sensing properties for $\mathrm{NO}$ and $\mathrm{NO}_{2}$ at $400^{\circ} \mathrm{C}$ on $100 \mathrm{kHz}$.
\end{abstract}

Key words: Impedance, Nitrogen oxide, Gas sensor, Nickel oxide, YSZ

\section{Introduction}

Nitrogen oxides (NOx; $\mathrm{NO}, \mathrm{NO}_{2}$ ) emissions in exhaust gases coming from automobiles have been becoming the cause of atmospheric pollutants such as an acid rain and photochemical smog. ${ }^{[1]}$ Therefore, monitoring of the exact amount of NOx and development of compact sensors applicable to automobiles are becoming important for the protection of global environments. So far, various types of NOx gas sensors, including semiconductor type ${ }^{[2]}$ solid electrolyte-based potentiometric type ${ }^{[3,4]}$ amperometric type ${ }^{[5]}$ and impedancemetric type $^{[1]}$ sensors, have been investigated. Yttriastabilized zirconia (YSZ)-based gas sensors are considered to be one of candidates for reliable sensor material. ${ }^{[6]}$ Also, the solid electrolyte type is of particular interest from the viewpoints of sensitivity, selectivity, and stability at high temperatures. ${ }^{[7,8]}$ Therefore, we have proposed and investigated a new concept of a solid-state NOx sensor combined with an YSZ plate as an impedance transducer and metal oxides $\left(\mathrm{Fe}_{2} \mathrm{O}_{3}\right.$, $\mathrm{Co}_{3} \mathrm{O}_{4}, \mathrm{NiO}, \mathrm{CuO}, \mathrm{ZnO}$ ) as a receptor. ${ }^{[4,7,8]}$ The new type of impedancemetric sensor has an advantage in its simple sensor structure, in which there is no need for reference and/or counter electrodes at the opposite side of the senor device. An impedancemetric solid-state sensor using a zirconia solid electrolyte transducer attached to an oxide layer as a gassensing receptor showed relatively good NOx sensing properties; however, the impedance changes as the response intensity were as low as several percent for practical applications. ${ }^{[4,7]}$ In this study, we used yttria-stabilized zirconia as a solid electrolyte transducer and metal oxides as a receptor for a new type of simple solid-state impedancemetric NOx sensor. We report the NOx sensing performance and the effect of the receptor materials on the impedancemetric solid electrolyte NOx sensor.

\section{Experimental}

The sensor device was fabricated using an 8 mol\%-YSZ plate (Nikkato Corp., Japan) as a transducer and reagent-grade metal oxide $\left(\mathrm{Fe}_{2} \mathrm{O}_{3}, \mathrm{Co}_{3} \mathrm{O}_{4}, \mathrm{NiO}, \mathrm{CuO}, \mathrm{ZnO}\right)$ as receptors. The sensor consisted of an YSZ plate $(10 \times 10 \times 1 \mathrm{t} \mathrm{mm})$, a receptor layer, and two $\mathrm{Au}$ electrodes at the opposite surface of the YSZ plate as shown in Fig. 1. The Au electrodes were tightly coated with an inorganic adhesive (ARON CERAMIC, TOAGOSEI, Japan). A receptor paste prepared with the appropriate amount of oxide and $\alpha$-terpineol was painted onto the surface of the YSZ plate, and then the plate was dried and sintered at $500^{\circ} \mathrm{C}$ for $2 \mathrm{~h}$. NOx sensing experiments were carried out in a conventional flow apparatus equipped with a heating facility at $300 \sim 500^{\circ} \mathrm{C}$. 


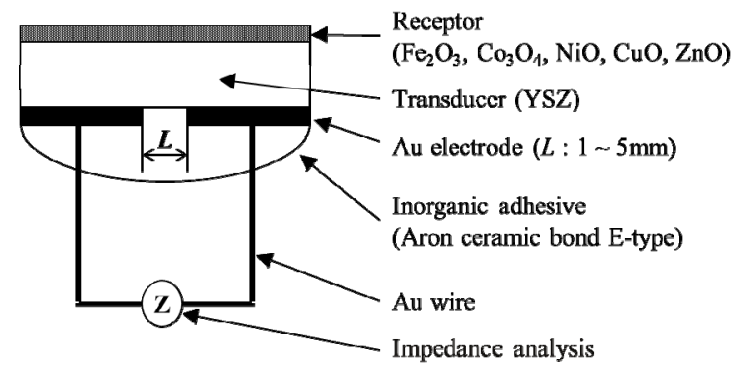

Fig. 1. Schematic diagram of the impedancemetric sensor device.

Nyquist's plots of this sensor were measured between $50 \mathrm{~Hz}$ and $5 \mathrm{MHz}$, and the sensor responses (resistance and capacitance) were measured at various concentrations of each NOx gas with an impedance analyzer (LCR 3532-50, HIOKI, Japan). Sample gases containing $\mathrm{NO}$ or $\mathrm{NO}_{2}$ were prepared from each parent gas at a fixed $\mathrm{O}_{2}$ pressure of $21 \mathrm{vol} \%$ and $\mathrm{NO}$ diluted with nitrogen or $\mathrm{NO}_{2}$ diluted with a dry synthetic air $\left(79 \mathrm{vol} \% \mathrm{~N}_{2}+21 \mathrm{vol} \% \mathrm{O}_{2}\right.$ gas mixture), by mixing it with $\mathrm{N}_{2}(99.999$ vol\%) or air at a total flow rate of $100 \mathrm{ml} / \mathrm{min}$.

\section{Results and Discussion}

Nyquist's plots between $\mathrm{Au}$ electrodes at the YSZ layer of the oxide/YSZ sensor showed that impedance change at various concentrations of NOx was caused at the interface impedance area. ${ }^{[1]}$ We investigated the response property of the sensor at the fixed frequency of $100 \mathrm{kHz}$ as a sensing signal, because response change was observed from $100 \mathrm{kHz}$ as shown in Fig. 2.

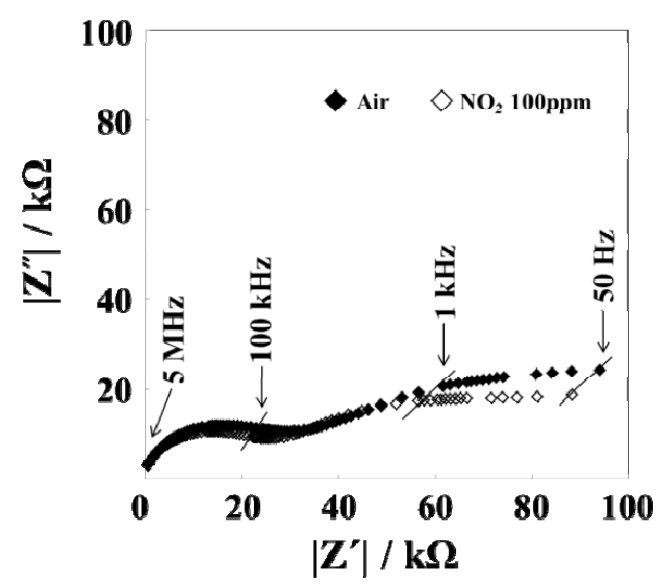

Fig. 2. Nyquist's plots of the NiO/YSZ sensor in air and $\mathrm{NO}_{2}$ at $400^{\circ} \mathrm{C}$

Responses of the NOx sensors could be obtained and they could be divided into resistance and capacitance components. Figure 3 shows response curves of each resistance component (R) and capacitance component $(\mathrm{C})$ of the $\mathrm{NiO} / \mathrm{YSZ}$ sensor for various concentrations of $\mathrm{NO}$ and $\mathrm{NO}_{2}$ at $400^{\circ} \mathrm{C}, 100 \mathrm{kHz}$.
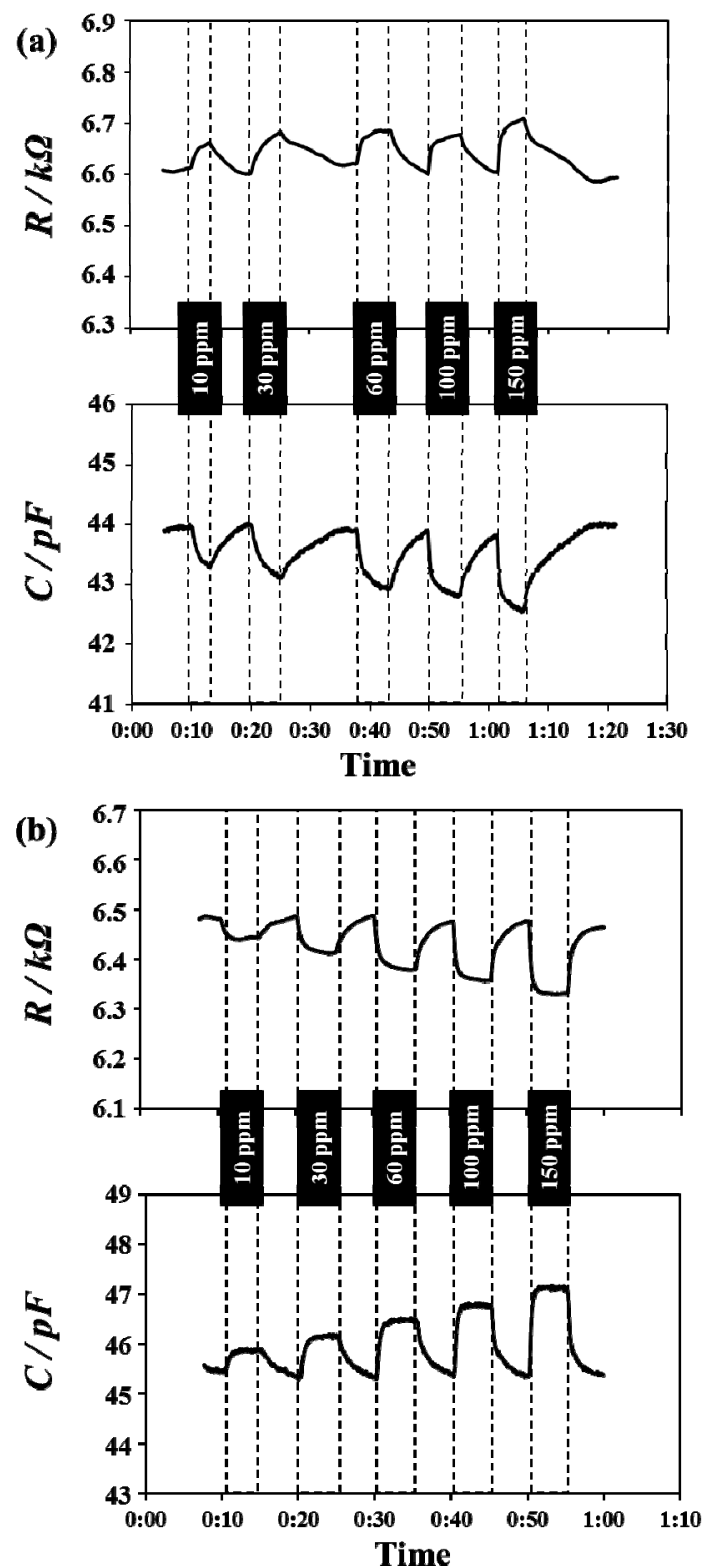

Fig. 3. Sensing response curves of the NiO/YSZ sensor for various concentrations of $\mathrm{NO}$ (a) and $\mathrm{NO}_{2}$ (b) at $400^{\circ} \mathrm{C}, 100 \mathrm{kHz}$.

In the case of $\mathrm{NO}$, the response curve of the resistance component $(R)$ tended to increase with increasing $\mathrm{NO}$ concentration, while the capacitance component (C) decreased. Also, the response curve of $\mathrm{NO}_{2}$ showed good response sensitivity and stability as both the resistance component (R) and capacitance component (C); the resistance decreased and capacitance increased with increase in $\mathrm{NO}_{2}$ concentration. Moreover, this showed be applicable to selective sensing by sensing performance of negative response for $\mathrm{NO}$ or positive response for $\mathrm{NO}_{2}$ on resistance component (R). The NiO/YSZ sensor showed excellent $\mathrm{NO}_{2}$ sensing response and good dependence for each $\mathrm{NO}_{2}$ concentration. In the same way, the other metal oxide receptors were examined. The sensitivities of each of the 
sensors for various receptor materials are summarized in Fig. 4. The response property of excellent resistance or capacitance change was observed in the case of $\mathrm{NiO}$ and/or $\mathrm{CuO}$. The value of the relative sensitivity $\left(S_{R}\right.$ or $\left.S_{C}\right)$ was defined as $S_{R}=\left(R_{\text {gas }}-R_{\text {air }}\right) / R_{\text {air }} \times 100(\%)$ or $S_{C}=\left(C_{\text {gas }}-C_{\text {air }}\right) / C_{\text {air }} \times 100(\%)$, in which $R_{\text {gas }}\left(C_{\text {gas }}\right)$ and $R_{\text {air }}\left(C_{\text {air }}\right)$ is resistance (capacitance) in gas and that in air, respectively. The sensitivities of these sensors were affected by the ability of the receptor materials used to detect the gas at different NOx concentrations, and the $\mathrm{NiO}$ receptor showed the highest sensitivity among the sensors.

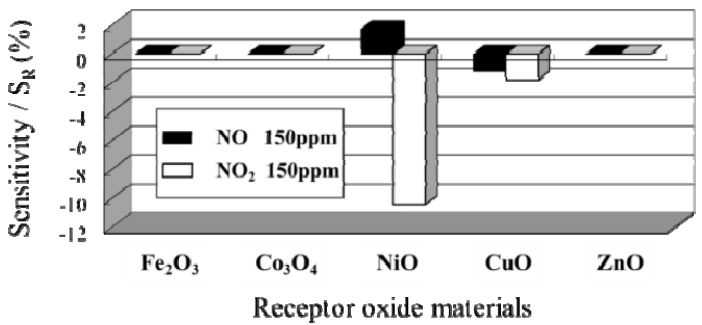

Fig. 4. Sensitivities of the impedancemetric sensor device for various receptor materials at $400{ }^{\circ} \mathrm{C}, 100$ $\mathrm{kHz}$.

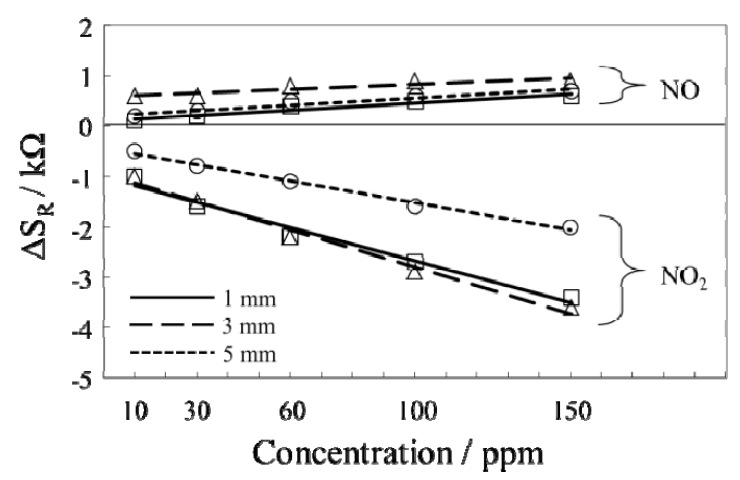

Fig. 5. Effect of Au electrode distance on the $\mathrm{NiO} / \mathrm{YSZ}$ sensor for various concentrations of NO and $\mathrm{NO}_{2}$ at $400{ }^{\circ} \mathrm{C}, 100 \mathrm{kHz}$.

We also investigated the effect of distance between $\mathrm{Au}$ electrodes, and the results are presented in Fig. 5. The results showed that the sensing property of the NiO/YSZ sensor was weakened by increase in electrode distance from $1 \mathrm{~mm}$ to $5 \mathrm{~mm}$.

Tab. 1: Table caption Sensing response property of $\mathrm{NiO}$ YSSZ sensor for various working temperatures.

\begin{tabular}{|c|c|c|c|c|c|}
\hline \multirow{2}{*}{$\begin{array}{c}\text { Temp. } \\
\left({ }^{\circ} \mathrm{C}\right)\end{array}$} & \multicolumn{4}{|c|}{ Sensitivity (\%) } & \multirow{2}{*}{ Stability } \\
\cline { 2 - 5 } & $\mathrm{NO} 100 \mathrm{ppm}$ & $\mathrm{NO}_{2} 100 \mathrm{ppm}$ & \\
\hline 300 & $\mathrm{~S}_{\mathrm{R}}$ & $\mathrm{S}_{\mathrm{C}}$ & $\mathrm{S}_{\mathrm{R}}$ & $\mathrm{S}_{\mathrm{C}}$ & \\
\hline 400 & 1.30 & -0.60 & -2.40 & 0.73 & Poor \\
\hline 500 & 0.28 & -0.83 & -0.54 & 0.74 & Fair \\
\hline
\end{tabular}

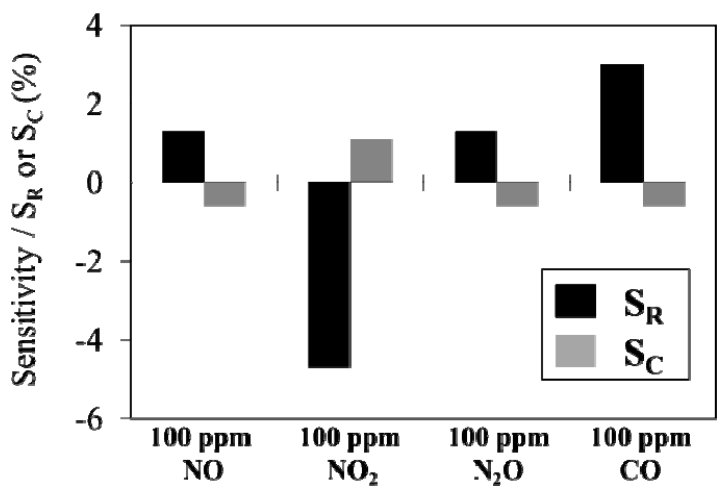

Fig. 6. Sensitivities of the NiO/YSZ sensor for various gases at $400^{\circ} \mathrm{C}, 100 \mathrm{kHz}$

Therefore, we fixed the receptor material and electrode distance as $\mathrm{NiO}$ and $1 \mathrm{~mm}$. In this condition, the effect of working temperature was examined from 300 to $500{ }^{\circ} \mathrm{C}$. The sensitivity and stability of the $\mathrm{NiO} / \mathrm{YSZ}$ sensor at various working temperatures are summarized in Table 1. The response properties of the NiO/YSZ sensor could be obtained good properties for $\mathrm{NO}_{2}$, at $400^{\circ} \mathrm{C}$. Moreover, the response properties showed good selective and stable performance for $\mathrm{NO}_{2}$. This results showed be applicable to selective sensing by $\mathrm{NO}_{2}$. The $\mathrm{NiO} / \mathrm{YSZ}$ sensor showed good sensitivity for $\mathrm{NO}_{2}$ but not for the other gases as shown Fig. 6 . The sensing mechanism of the NiO/YSZ sensor is shown schematically in Fig. 7. First, the $\mathrm{NiO} / \mathrm{YSZ}$ sensor is exposed to clean air, and then oxygen ions $\left(\mathrm{O}^{-}\right)$would form at the surface of $\mathrm{NiO}$ in a sequence of physisorption and

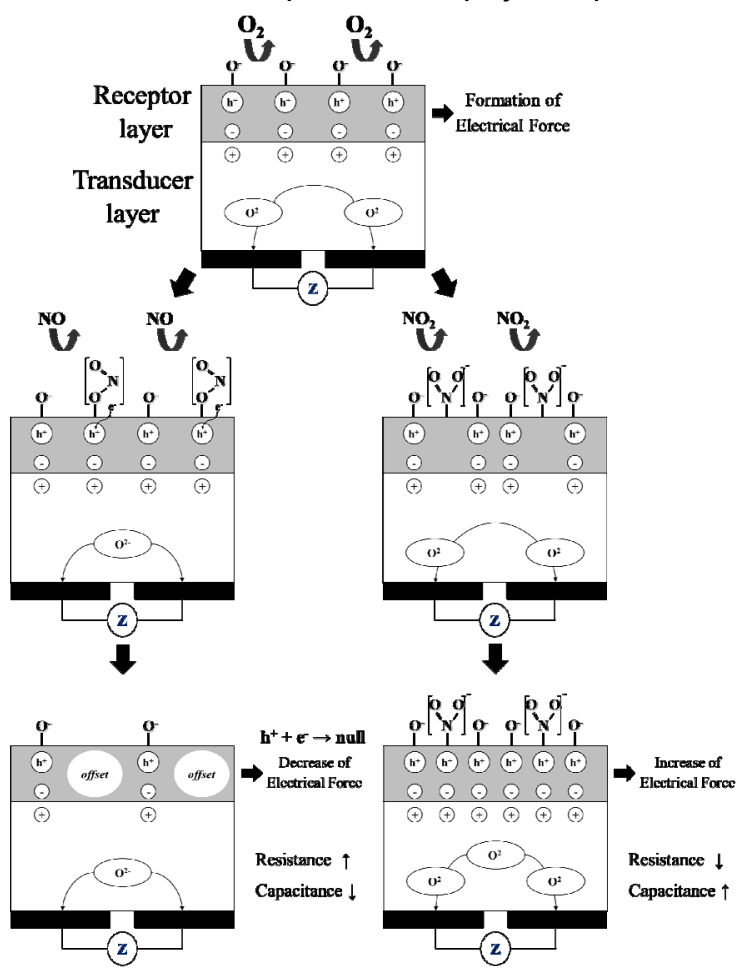

Fig. 7. Sensing mechanism of the NiO/YSZ sensor for response of NOx. 
charge exchange reactions with the bulk of $\mathrm{NiO}$ grains, as described by Eq. (1). The adsorption of oxygen ions would result in the generation of electrical force by polarization in the receptor layer. After the $\mathrm{NiO} / \mathrm{YSZ}$ sensor has been exposed to $\mathrm{NO}$, the $\mathrm{NO}$ gas would react with $\mathrm{O}^{-}$(ads), as Eq. (2), and cause reduction of holes in the receptor layer, resulting in a decrease in the electrical force. For this reason, the resistance component of the $\mathrm{NiO} / \mathrm{YSZ}$ sensor decreases.

$$
\begin{aligned}
& \mathrm{O}_{2} \rightarrow 2 \mathrm{O}^{-}{ }_{(\text {ads })}+\mathrm{h}^{+} \\
& \mathrm{NO}+\mathrm{O}^{-} \text {(ads) } \rightarrow \mathrm{NO}_{2}+\mathrm{e}^{-}
\end{aligned}
$$

On the other hand, when the $\mathrm{NiO} / \mathrm{YSZ}$ sensor is exposed to $\mathrm{NO}_{2}, \mathrm{NO}_{2}$ would react with the receptor layer, as Eq. (3), and cause an increase in holes by adsorption of $\mathrm{NO}_{2}{ }^{-}$, resulting in a decrease in the resistance component.

$$
\mathrm{NO}_{2} \rightarrow \mathrm{NO}_{2}^{-}{ }_{(\text {ads })}+\mathrm{h}^{+}
$$

Thus, it is thought that the sensing response occurs at the receptor layer due to adsorption of $\mathrm{O}_{2}$ and/or NOx on the surface of the receptor.

\section{Acknowledgements}

This work was partially supported by the NISSAN Science Foundation, Japan and by the International Cooperative Subject for Industrial-
Academic Common Technology Development (200800030050) of SMBA for Collaboration R\&D between Industry and Academy, Korea.

\section{References}

[1] H.C. Cho, S. Kuramoto, S. Takase, J.H. Song, Y. Shimizu, Sensors and Materials 24 (1), 31-41 (2011)

[2] M. Akiyama, Z. Zhang, J. Tamaki, N. Miura, N. Yamazoe, T. Harada, Sens. Actuator B 14 (1-3), 619-620 (1993); doi: 10.1016/09254005(93)85117-S

[3] Jinsu Park, B.Y. Yoon, C.O. Park, Won-Jun Lee, C.B. Lee, Sens. Actuator B 135 (2), 516-523 (2009); doi: 10.1016/j.snb.2008.10.006

[4] P. Elumalai, V.V. Plashnitsa, Y. Fujio, N. Miura, Sens. Actuator B 144 (1), 215-219 (2010); doi: 10.1016/j.snb.2009.10.063

[5] M. Ono, K. Shimanoe, N. Miura, N. Yamazoe, Solid State Ionics 136-137 (SI), 583-588(2000); doi: 10.1016/S0167-2738(00)00341-6

[6] S.A. Anggraini, V.V. Plashnitsa, P. Elumalai, M. Breedon, N. Miura, Sensors and Actuator B 160 (1), 1273-1281 (2011); doi: 10.1016/j.snb.2011.09.062

[7] D. Koba, S. Takase, Y. Shimizu, ECS Transactions 3(10), 163-171 (2006); doi: 10.1149/1.2357256

[8] S. Tamura, I. Hasegawa, N. Imanaka, Sens. Actuator B 130 (1), 46-51 (2008); doi: 10.1016/j.snb.2007.07.077 